\title{
Introduction to the JCIHE Spring 2020 Issue
}

\author{
Rosalind Latiner Raby \\ California State University, Northridge, USA \\ Email: rabyrl@aol.com \\ Address: 18111 Nordhoff Street Northridge, CA 91330-8265, California, USA
}

\section{Dear Readers -}

I am pleased to share the Spring 2020 issue of the Journal of Comparative and International Higher Education (JCIHE). JCIHE is the flagship journal of the Comparative and International Education Society (CIES) Higher Education SIG. The articles in the journal include original research that is used in practice as well as in bringing advances in understanding of methods, theories, and application of comparative and international higher education. Submissions include a range of contexts, perspectives, methodologies, and intersections of disciplines. The Spring 2020 issue includes six articles that explore applications of comprehensive internationalization and that utilize new methodologies to critically reflect on how traditional constructs exits within new contexts.

Two of the articles utilize the construct of comprehensive internationalization (Hudzik 2011) and apply it to the interconnectedness of programs, policies, and practices at their case-study institutions. Sarita Rai, in "Making a Case For An Integrated Faculty-Designed and Faculty-Operated Study Abroad Center" uses a case study of the University of Hawai'I Mānoa Study Abroad Center to show how student success in studying abroad is connected to the existence of a solid Study Abroad Center that uses comprehensive internationalization to build faculty engagement, shared governance, and support from executive officers that define that center as an academic unit with academic commitments. Ielyzaveta Shchepetylnykova and Samantha Alvis, in "Contribution of International Development Activities to Comprehensive Internationalization of U.S. Public Universities" examines an understudied aspect of comprehensive internationalization in US universities, that of international development. One form of international development is university engagement which the authors suggest is fundamental in how international development activities advance core education, research, and service missions of HEIs.

The other four articles in the Spring 2020 issue question traditional thinking and discourse on comparative and international higher education. By using non-traditional methodologies and by using critical analysis, these authors examine similar situations but in a different context. Santiago Castiello-Guitierrez, in "No Fees to Enroll Them All? The State of College Access in México" explores the situation in which the Mexican federal government, along with the public and private educational institutions, have implemented different approaches to increase educational access. The article conducts a critical policy analysis of legislation that made higher education compulsory and uses holistic analysis to show the need to include issues of equity and quality when focusing on increasing access. Renee Drabier and Carol P. Fimmen in "A Qualitative Analysis: Mexican University Student Written Advice to Future Students at the Conclusion of a Semester Abroad Experience" examines peer mentoring in a case study of the Alamo Community College District Bécalos Program. The article uses student journaling to create new discourses on how to use student voices to effectively peer mentor new generations of students. In particular, the article shows how peer advice from one class of Mexican student to the next provides information that will help to improve their future student experiences as well as to inform structural changes to the program itself.

Peace Ginika Nwokedi and Fumane P. Khanare, in "Thriving in the Face of Adversity: Mapping Experiences of International Students in a South African Higher Education Institution" explore an under-studied population of international students who are studying in a South Africa HEI by using the photo-voice methodology to critically 
assess how student voices that are largely unheard. They also show how by recognizing this silence it can inform reform efforts in regard to their experiences and wellbeing in South Africa. Finally, William Geibel, in "A Pedagogy of Student Mobility: Facilitating Humanistic Outcomes in Internationalization and Student Mobility" questions the traditional belief that attendance alone can facilitate humanistic outcomes commonly associated with student mobility. By using a pedagogy of student mobility, the author critically assesses that for success, mobility needs to be seen as an educational activity that is facilitated by the university in specific and designated practices.

As JCIHE growths in breadth and depth, it is important to continually refine a structure that is useable for our readership. Widespread recognition of the importance of comparative and international higher educational themes in a variety of educational fields drives the need continually to broaden the focus of the journal. These emerging issues cross national boundaries and in so doing build new patterns of publishing to help to better understand the state of our field. Special thanks are given to the JCIHE Managing Editor, Dr. Hayes Tang for his support, insight, and creativity.

Editor-in-Chief,

Rosalind Latiner Raby, Ph.D.

Spring 2020

\section{References}

Hudzik, John K. 2001. Comprehensive Internationalization. From Concept to Action. www.nafsa.org/_File/_/downloads/cizn_concept_action.pdf 